Article

\title{
Assessment of Areal Methane Yields from Energy Crops in Ukraine, Best Practices
}

\author{
Ievgeniia Morozova $^{1, *(\mathbb{D}, \text { Hans Oechsner }}{ }^{1} \mathbb{D}$, Mykola Roik $^{2}$, Benedikt Hülsemann ${ }^{1}$ and $^{-}$ \\ Andreas Lemmer ${ }^{1}$ \\ 1 State Institute of Agricultural Engineering and Bioenergy, University of Hohenheim, \\ 70599 Stuttgart, Germany; Hans.Oechsner@uni-hohenheim.de (H.O.); \\ Benedikt.Huelsemann@uni-hohenheim.de (B.H.); andreas.lemmer@uni-hohenheim.de (A.L.) \\ 2 Institute of Bioenergy Crops and Sugar Beet of the Agrarian Academy of Sciences of Ukraine, \\ 03110 Kiev, Ukraine; roiknik@ukr.net \\ * Correspondence: ievgeniia.morozova@uni-hohenheim.de; Tel.: +49-711-459-23348; \\ Fax: +49-(0)711-459-22111
}

Received: 29 May 2020; Accepted: 24 June 2020; Published: 27 June 2020

\begin{abstract}
Growing and utilizing bioenergy crops as feeding substrates in biogas plants may aid the development of the biogas sector in Ukraine. Therefore, research was done on potential methane yields from 22 high-yield varieties of 7 different crops grown in Ukraine for their biogas production suitability. Annual crops (maize, soybean, sweet sorghum and sorghum hybrids) and perennials (miscanthus, paulownia and switchgrass) harvested at three different harvesting times (H1, H2 and H3) related to specific stages of phenological development were investigated. The perennial crops studied were from different vegetation years. The samples were analysed in Ukraine on their dry matter- and volatile solids contents, dry matter yield (DMY) and crop nitrogen (N) uptake. The $55^{\circ} \mathrm{C}$ -dried samples were delivered to Germany for their analysis with the Hohenheim Biogas Yield Test (HBT) on their specific methane yield (SMY). Based on DMY and SMY, the areal methane yields (AMY) were calculated. The highest SMY and AMY were found for maize, sweet sorghum and miscanthus. The highest average SMY of $0.35 \pm 0.03 \mathrm{~m}^{3} \mathrm{CH}_{4} \mathrm{kgVS}^{-1}$ was found for maize samples harvested at H2. Miscanthus "Giganteus" from the 8th vegetation year harvested at H1 has shown the highest AMY of $7404.50 \pm 199.00 \mathrm{~m}^{3} \mathrm{CH}_{4} \mathrm{ha}^{-1}$.
\end{abstract}

Keywords: anaerobic digestion; biogas; maize; soybean; sorghum; miscanthus; switchgrass; paulownia; $\mathrm{BBCH}$-code; nitrogen use efficiency

\section{Introduction}

In 2018, the natural gas import in Ukraine amounted to $35.7 \%$ of the total gas consumption [1]. The topical issue is to reduce the natural gas import, which can be done through the production of biogas. According to Scarlat et al. [2], the biogas production in Ukraine in 2015 sums up to $600 \mathrm{TJ}$ or $117 \mathrm{mil} \mathrm{m}^{3}$, while the biogas share in the natural gas use was only $0.1 \%$. In 2018 this share increased to $0.2 \%$ [1]. End of 2019, the installed power capacity of biogas plants in Ukraine amounted to $70 \mathrm{MW}$ power capacity, where $47 \mathrm{MW}$ of these units are based on agricultural wastes and the remaining run on landfill gas [3].

In the development of Ukraine's biogas sector, the availability of feedstock plays one of the key roles. As of February 2020, the existing agricultural biogas plants in Ukraine utilize the following substrates: pig and cattle manure, poultry litter, sugar-beet pulp, sugar sorghum silage and maize silage. It is noteworthy that in Ukraine there is a limited amount of manure due to a constant decreasing trend in livestock breeding except for poultry [1]. Therefore, alternative biogas substrates other than manure or poultry litter should be investigated. 
To provide continuous availability of substrates supplies in biogas plants, different bioenergy crops cultivated in Ukraine specifically for biogas production can be utilized. Currently, Ukraine does not have a deficiency in the food crops availability which is in correspondence to its relatively low population density of 69.49 inhabitants per $\mathrm{km}^{2}$ (in Germany the population density is 233, in China-146); moreover, Ukraine is one of the leading grain exporting nations in the world [1,4]. As the area of agricultural lands in Ukraine as of 01.01 .2016 amounted to $42,726.4$ thousand hectares or $70.8 \%$ of the total area of Ukraine [5], a part of bioenergy crops can be grown on underutilized agricultural lands or in sustainable rotations with other crops. Furthermore, experts assess the area of marginal lands in Ukraine to be $\sim 4$ million hectares for the inland territory [6,7], where the bioenergy crops can be additionally cultivated. Therefore, due to the land's availability, bioenergy crops are a potentially attractive substrate for biogas production in Ukraine. Additionally, since December 2019 the State Agency on Energy Efficiency and Energy Saving of Ukraine has been requesting the approval of the amendments to the Ukrainian legislation that should provide a state support program for the cultivation of bioenergy crops [8].

The biogas production from bioenergy crops is directly related to the value of crop's areal methane yield (AMY), measured in $\mathrm{m}^{3} \mathrm{CH}_{4} \cdot \mathrm{ha}^{-1}$ [9]. For bioenergy crops, the AMY depends on many parameters: crop species [9-11], crop variety [12-14], soil-climatic conditions [11], average temperature and precipitation during the cultivation period [15-18], dosage of fertilizer applied [16,19,20], harvesting time related to specific stages of crop phenological development $[9,11-15,19,21-24]$, pretreatment, especially for lignocellulosic biomass [23,25-28] among others.

No literature was found on AMY of bioenergy crops grown in Ukraine. Since the soils and climatic conditions in Ukraine differ significantly from those of Western European countries, the experience gained in energy crops cultivation in these countries cannot be directly transferred to Ukraine. For this reason, the study on the assessment of AMY of high-yield bioenergy crops grown in Ukraine has to be conducted.

In this study, the effects of harvesting time and vegetation year (for perennials) on AMY of potential Ukrainian energy crops are studied. Additionally, the effects of dry matter yield (DMY) and crop $\mathrm{N}$ uptake on AMY are determined.

\section{Materials and Methods}

\subsection{Experiment Overview}

Ukraine has a temperate climate except on the southern coast of Crimea, which has a subtropical climate. Ukrainian climate conditions are favourable for growing the following bioenergy crops further discussed in this paper: soybean, maize, sweet sorghum and sorghum hybrids (e.g., rice sorghum, known in Ukraine as soriz) [29], switchgrass, miscanthus and paulownia (see Table 1). For this research, high-yield varieties of the above-mentioned crops suitable for dissemination in Ukraine according to the State Register were selected [30], thus leading to a total of 22 varieties of 7 crops, each harvested at three different harvesting times. For perennials, additionally, the effect of the age of plantation (known also as crop vegetation year) on AMY was investigated. 
Table 1. The basic characteristics of the bioenergy crops.

\begin{tabular}{|c|c|c|c|c|c|}
\hline Name of Plant & $\begin{array}{l}\text { Climate } \\
\text { Preference }\end{array}$ & $\begin{array}{c}\text { Carbon } \\
\text { Fixation }\end{array}$ & Annual/Perennial & Class & Reference \\
\hline Soybean & Cool season & $\mathrm{C} 3$ & Annual & Legume & \multirow{7}{*}[11,16,31-35]{} \\
\hline Maize & Warm season & $\mathrm{C} 4$ & Annual & Grass & \\
\hline Sweet sorghum & Warm season & $\mathrm{C} 4$ & Annual & Thick-stemmed grass & \\
\hline $\begin{array}{l}\text { Sorghum oryzoidum } \\
\text { or rice sorghum (soriz) }\end{array}$ & Warm season & $\mathrm{C} 4$ & Annual & Thick-stemmed grass & \\
\hline Switchgrass & Warm season & $\mathrm{C} 4$ & Perennial & Thin-stemmed grass & \\
\hline Miscanthus & Cool season & $\mathrm{C} 4$ & Perennial & Thick-stemmed grass & \\
\hline Paulownia & Warm season & $\mathrm{C} 3$ & Perennial & Fast growth coppice & \\
\hline
\end{tabular}

\subsection{Field Trials and Plant Material}

\subsubsection{Field Trials}

The analysed crops were cultivated in 2017 at the fields of the Agrarian Academy of Sciences of Ukraine. The location of the fields: Kiev and Kiev region (Vasylkiv district, urban-type settlement Grebinky; the research enterprise and research household "Salyvinkivske"; latitude $49.6^{\circ} \mathrm{N}$, longitude $30.1^{\circ} \mathrm{E}$, altitude $178 \mathrm{~m}$ ). 18 varieties were cultivated in the Kiev region; 4 varieties were grown on the research fields of the Institute of Bioenergy Crops and Sugar Beet in Kiev.

The fields belong to an area with a mean annual temperature of $10^{\circ} \mathrm{C}$. The crops were grown in a zone of unstable humidity with a mean annual precipitation of $341.1 \mathrm{~mm}$.

The crops were cultivated on the typical medium-loamy black soils with loessial loam and a humus range of $2.68 \% \pm 0.35 \%$. The soils contained low-medium nitrogen $(\mathrm{N})$ contents: $181.67 \pm 78.72 \mathrm{mg} \mathrm{N}$ per g air-dry soil. The $\mathrm{pH}$ of the soils was $6.64 \pm 0.09$.

During the crop cultivation period in 2017 at the field locations, there was a higher average monthly temperature and a lower average monthly precipitation in comparison to those values in the years 1985-2016 (see Figure 1). Due to the unfavourable weather conditions, the losses in DMY and thus in AMY could take place.

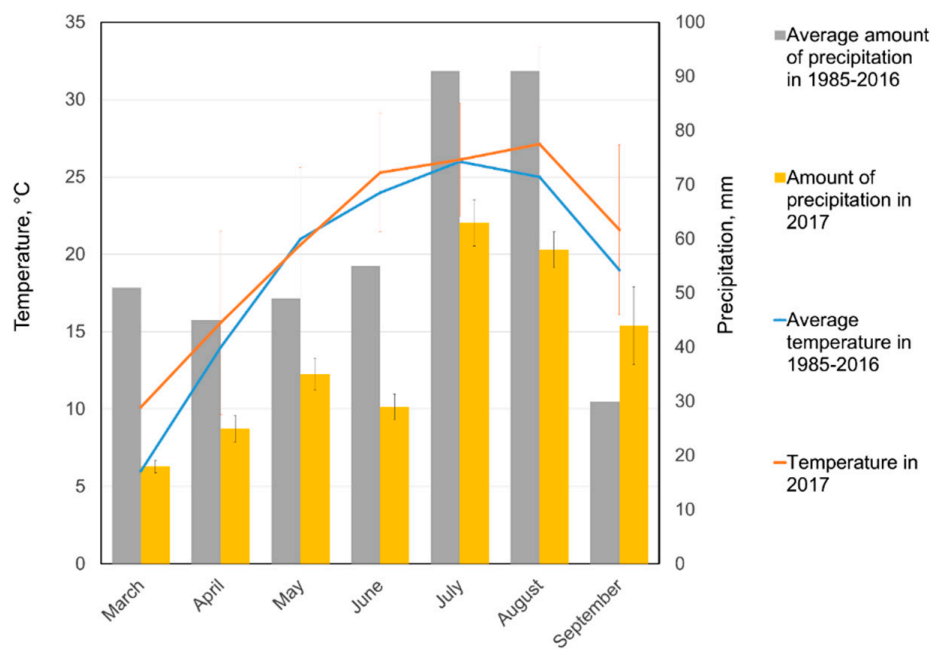

Figure 1. The comparison of weather conditions, such as monthly temperature and monthly precipitation, at the field locations during the cultivation period of the crop samples in 2017 with those values in years 1985-2016. Error bars indicate the monthly variability of temperature and precipitation in 2017.

As the amount of rainfall on-site was considered to be sufficient for cultivation, the field plots were not artificially irrigated. 


\subsubsection{Plant Material}

Plant material was provided by the Institute of Bioenergy Crops and Sugar Beet of the Agrarian Academy of Sciences of Ukraine. The high-yield varieties were selected for this investigation. The analysed amount of varieties per crop were as follows: 5 for soybean; 6 for maize; 4 for sweet sorghum; 3 for sorghum orysoidum; 1 for switchgrass harvested at the 2 nd and the 8 th vegetation years; 2 for miscanthus, where both varieties were harvested at the 3 rd year of vegetation and one of them was also harvested at the 8 th vegetation year; 1 variety of paulownia from the 1 st vegetation year.

The fertilizers were applied to the fields in the dosage as recommended for each crop by the Institute of Bioenergy Crops and Sugar Beet taking into account the chemical content of the soil and the plants' demands (see Table 2). Herbicides and fungicides were conventionally applied at the individual locations.

Table 2. Fertilizer application at the fields where the analysed bioenergy crops were cultivated.

\begin{tabular}{|c|c|c|c|}
\hline Name of Plant & Fertilizer & Dosage Applied & Application Time \\
\hline Soybean & $\begin{array}{c}\text { Ammonia nitrate }\left(\mathrm{NH}_{4} \mathrm{NO}_{3} \text {, }\right. \\
\text { consists } \\
34.5 \% \mathrm{~N})\end{array}$ & $100 \mathrm{~kg} \mathrm{ha}^{-1}$ & $\begin{array}{l}\text { Application during } \\
\text { presowing cultivation }\end{array}$ \\
\hline \multirow[t]{2}{*}{ Maize } & $\begin{array}{c}\text { Nitroammophos } \\
\left(\mathrm{NH}_{4} \mathrm{NO}_{3}+\mathrm{NH}_{4} \mathrm{H}_{2} \mathrm{PO}_{4}\right. \\
\text { consists } 21.0-25.0 \% \mathrm{~N} \\
\left.20.0-25.5 \% \mathrm{P}_{2} \mathrm{O}_{5}\right)\end{array}$ & $150 \mathrm{~kg} \mathrm{ha}^{-1}$ & $\begin{array}{l}\text { Application in autumn } \\
\text { before plowing }\end{array}$ \\
\hline & $\begin{array}{l}\text { Ammonia nitrate }\left(\mathrm{NH}_{4} \mathrm{NO}_{3}\right. \\
\text { consists } 34.5 \% \mathrm{~N})\end{array}$ & $300 \mathrm{~kg} \mathrm{ha}^{-1}$ & $\begin{array}{l}\text { Post-emergence } \\
\text { fertilizing }\end{array}$ \\
\hline $\begin{array}{l}\text { Sweet sorghum, } \\
\text { Sorghum oryzoidum or } \\
\text { rice sorghum (soriz) }\end{array}$ & $\begin{array}{c}\text { Superphosphate } \\
\text { (consists 14.0-21.0\% } \mathrm{P}_{2} \mathrm{O}_{5} \text { ) }\end{array}$ & $200 \mathrm{~kg} \mathrm{ha}^{-1}$ & $\begin{array}{l}\text { Post-emergence } \\
\text { fertilizing }\end{array}$ \\
\hline Switchgrass & $\begin{array}{c}\text { Superphosphate } \\
\text { (consists 14.0-21.0\% } \mathrm{P}_{2} \mathrm{O}_{5} \text { ) }\end{array}$ & $200 \mathrm{~kg} \mathrm{ha}^{-1}$ & $\begin{array}{l}\text { Application during } \\
\text { presowing cultivation }\end{array}$ \\
\hline Miscanthus & $\begin{array}{c}\text { Superphosphate } \\
\text { (consists 14.0-21.0\% } \mathrm{P}_{2} \mathrm{O}_{5} \text { ) }\end{array}$ & $200 \mathrm{~kg} \mathrm{ha}^{-1}$ & $\begin{array}{l}\text { Application during } \\
\text { cultivation, before } \\
\text { planting the rhizomes }\end{array}$ \\
\hline Paulownia & $\begin{array}{c}\text { Ash (consists } \sim 4.6 \% \mathrm{P}_{2} \mathrm{O}_{5}, \\
\sim 3.2 \% \mathrm{~K}_{2} \mathrm{O} \text { ) }\end{array}$ & $\begin{array}{l}16,000 \mathrm{~kg} \mathrm{ha}^{-1}(1 \mathrm{~kg} \text { of } \\
\text { ash per plant })\end{array}$ & $\begin{array}{l}\text { Application during hole } \\
\text { planting of seedlings }\end{array}$ \\
\hline
\end{tabular}

The investigated crop varieties were harvested at three harvesting times, related to the different stages of crop phenological development which correspond to specific BBCH-codes $[14,32,33,35,36]$. The first harvesting time (H1) was between 01.08.17-03.08.17, the second $(\mathrm{H} 2)$ between 19.08.17-21.08.17, and the third (H3) between 31.08.17-01.09.17, as recommended by the Institute of Bioenergy Crops and Sugar Beet.

For each sample, the above-ground part of the crops was cut. For each harvesting time and for each investigated crop variety, the fresh matter (FM) yields in $\mathrm{kg} \cdot \mathrm{ha}^{-1}$ were determined. These FM yields were determined based on the average weight of the plants, their germination rate, the planting density, and the plants' hectare population (amount of plants per hectare).

The dry matter $(\mathrm{DM})$ content related to $\mathrm{FM}\left(\mathrm{DM}_{\mathrm{FM}}\right)$ in the collected samples was measured immediately after harvesting. Subsequently, the dried samples were analysed on volatile solids content related to $\mathrm{DM}\left(\mathrm{VS}_{\mathrm{DM}}\right)$. The $\mathrm{DM}_{\mathrm{FM}}$ and $\mathrm{VS}_{\mathrm{DM}}$ of the samples (in \%) were determined by differential weighing before and after drying at $105^{\circ} \mathrm{C}$ for $24 \mathrm{~h}$ and by subsequent ashing at $550{ }^{\circ} \mathrm{C}$ for $8 \mathrm{~h}$, respectively by using standard methods [37,38].

DMY for the samples, in $\mathrm{t} \cdot \mathrm{ha}^{-1}$ were determined based on the FM yields and the $\mathrm{DM}_{\mathrm{FM}}$ values. Total Kjeldahl nitrogen (TKN) is expressed as total nitrogen or $\mathrm{N}$ if not stated otherwise. The total nitrogen in the samples was determined by Kjeldahl analysis [37,38]. The crop $\mathrm{N}$ uptake for the collected samples, in $\mathrm{kg}_{\mathrm{N}} \cdot \mathrm{ha}^{-1}$ was determined based on the crop $\mathrm{N}$ concentrations and their DMY. 
For futher analysis on the SMY with the Hohenheim Biogas Yield Test (HBT), collected crop samples were ground and dried at $55^{\circ} \mathrm{C}$ to a constant weight and they were subsequently delivered to Germany.

\subsection{SMY and $A M Y$}

\subsubsection{SMY}

The delivered dry crop samples were ground with a $1 \mathrm{~mm}$ grid size in the PULVERISETTE 19 cutting mill (Fritsch GmbH, Markt Einersheim, Germany). The samples were analysed in the HBT system as described in the literature $[13,39]$. The HBT experiment was conducted in $100 \mathrm{~mL}$ syringes, each filled with $400 \mathrm{mg}$ of the grounded substrate $\left(55^{\circ} \mathrm{C}\right.$-dried crop sample) and $30 \mathrm{~g}$ of inoculum (30 $\mathrm{mL}, 4.66 \% \mathrm{DM}, 2.82 \% \mathrm{VS}$ ) according to an inoculum to substrate ratio based on DM of 2:1 as recommended by VDI 4630 [40]. The standardized inoculum is cultivated in a 400 L laboratory reactor that was initially filled in with a biogas slurry and fed by a mixture of shredded wheat, soybean meal, rapeseed oil, maize silage and manure as described by Hülsemann et al. [41]. The experiment was conducted in accordance with standard methods [40] under mesophilic conditions of $37 \pm 0.5^{\circ} \mathrm{C}$ for a period of 35 days. In course of the fermentation process, the gas volume was manually recorded directly at the glass syringe in different time intervals (if at least $20 \mathrm{~mL}$ of gas was formed). The methane content was determined using an infrared-spectrometric methane sensor (Pronova Analysetechnik, Berlin, Germany). The experiment was performed in three repetitions. The results of the experiment are expressed in the determined specific methane yields for the samples in $\mathrm{m}^{3} \cdot \mathrm{kg}^{-1} \mathrm{VS}$. Gas yield was corrected at conditions of $273^{\circ} \mathrm{K}, 1.013$ bar (STP - standard temperature and pressure).

\subsubsection{AMY}

The areal methane yield of the crop samples, in $\mathrm{m}^{3} \mathrm{CH} 4 \cdot \mathrm{ha}^{-1}$ was calculated as defined by the following equation:

$$
A M Y_{i j}=S M Y_{i j} \cdot D M Y_{i j} \cdot\left(V S_{D M}\right)_{i j}
$$

where $i$ is related to an $i$-th crop variety, $j$ represents the $j$-th harvesting time; $S M Y_{i j}, D M Y_{i j}$ and $\left(V S_{D M}\right)_{i j}$ are specific methane yield, dry matter yield and volatile solids content related to dry matter for $i$-th variety and $j$-th harvesting time.

\subsection{Statistical Analysis}

For data processing and visualization, Microsoft EXCEL 2016, R and RStudio (version 1.1.463) and SAS 9.4 were used. In the statistical analysis, the Tukey-test and the generalized linear model function were applied

\section{Results and Discussion}

The maize, sweet sorghum and miscanthus have shown the highest values of SMY and AMY. Therefore, the results of these plants are first discussed separately. In the following section, there are combined the research results for soybean, soriz, switchgrass and paulownia. Finally, the effect of DMY on AMY and the specific nitrogen use efficiency of the plants were investigated.

\subsection{Maize}

Five varieties of maize (Zea mays L.) were analysed: "Varta MV" (FAO 280), "Shedevr MV" (FAO 320), "Slobozhans'kyi MV" (FAO 290), "Svitanok MV" (FAO 250) and "Kardynal MV" (FAO 280). The selected varieties represented a wide ripeness spectrum (FAO 250-320). While "Varta MV" and "Shedevr MV" are especially recommended for steppe zones, the variety "Slobozhans'kyi MV" is preferably grown on humid sites and the varieties "Svitanok MV" and "Kardynal MV" grow best in the steppe, forest-steppe and marshlands covered with shrubs known as "Polesia". 
According to literature, the highest methane yields for maize can be obtained when harvesting it in the vegetation stage of milk to wax ripeness (BBCH-codes 73-85) [12,23]. However, the timing of these vegetation stages depends on the crop variety and weather conditions. The values of $\mathrm{DM}_{\mathrm{FM}}$, $\mathrm{VS}_{\mathrm{DM}}$, DMY and crop N uptake are provided in Table 3; the SMY, AMY and BBCH-codes of the maize samples are given in Figure 2.

Table 3. Maize: DM and VS- content at harvest time, dry matter yield per hectare and N-uptake. Units are given in square brackets. Values are given as mean; standard deviation is given in round brackets.

\begin{tabular}{|c|c|c|c|c|c|}
\hline Cultivar & Harvesting Time & $\mathrm{DM}_{\mathrm{FM}}{ }^{*},[\%]$ & $\mathrm{VS}_{\mathrm{DM}}{ }^{* *},[\%]$ & $\begin{array}{c}\mathrm{DMY}^{* * *}, \\
{\left[\mathrm{t}_{\mathrm{DM}} \mathrm{ha}^{-1}\right]}\end{array}$ & $\begin{array}{c}\text { Crop N Uptake, } \\
{\left[\mathrm{kg}_{\mathrm{N}} \mathrm{ha}^{-1}\right]}\end{array}$ \\
\hline Kardynal MV & $\mathrm{H} 1$ & $24.4(1.10)$ & $93.9(4.22)$ & $7.30(0.33)$ & $55.45(2.46)$ \\
\hline Shedevr MV & $\mathrm{H} 1$ & $25.0(1.13)$ & $93.2(4.19)$ & $7.70(0.35)$ & $87.8(3.95)$ \\
\hline Slobozhans'kyi MV & H1 & $27.7(1.25)$ & $93.4(4.20)$ & $10.1(0.46)$ & $71.0(3.19)$ \\
\hline Svitanok MV & H1 & $24.3(1.09)$ & $93.7(4.22)$ & $9.75(0.44)$ & $116.9(5.26)$ \\
\hline Varta MV & H1 & $26.9(1.21)$ & $94.3(4.25)$ & $8.91(0.40)$ & $76.6(3.49)$ \\
\hline Kardinal MV & $\mathrm{H} 2$ & $25.8(0.52)$ & $96.5(1.93)$ & $7.71(0.15)$ & $58.63(1.17)$ \\
\hline Shedevr MV & $\mathrm{H} 2$ & $27.4(0.55)$ & $96.1(1.92)$ & $8.44(0.17)$ & $96.2(1.92)$ \\
\hline Slobozhans'kyi MV & $\mathrm{H} 2$ & $36.9(0.74)$ & $96.1(1.92)$ & $13.5(0.27)$ & $94.6(1.89)$ \\
\hline Svitanok MV & $\mathrm{H} 2$ & $25.6(0.51)$ & $81.3(1.63)$ & $10.3(0.21)$ & $123.24(2.47)$ \\
\hline Varta MV & $\mathrm{H} 2$ & $35.4(0.71)$ & $96.9(1.94)$ & $11.7(0.23)$ & $100.8(2.02)$ \\
\hline Kardinal MV & H3 & $39.4(1.10)$ & $95.4(2.67)$ & $11.78(0.33)$ & $89.5(2.51)$ \\
\hline Shedevr MV & $\mathrm{H} 3$ & $32.2(0.90)$ & $95.7(2.68)$ & $9.91(0.28)$ & $113.0(3.17)$ \\
\hline Slobozhans'kyi MV & $\mathrm{H} 3$ & $45.6(1.28)$ & $95.9(2.69)$ & $16.7(0.47)$ & $116.8(3.27)$ \\
\hline Svitanok MV & H3 & $44.0(1.23)$ & $97.3(2.72)$ & $17.7(0.49)$ & $211.8(5.93)$ \\
\hline Varta MV & H3 & $52.2(1.46)$ & $97.2(2.72)$ & $17.3(0.48)$ & $148.7(4.16)$ \\
\hline
\end{tabular}

* The dry matter content related to fresh matter, ${ }^{* *}$ Volatile solids content related to dry matter, ${ }^{* * *}$ Dry matter yield.

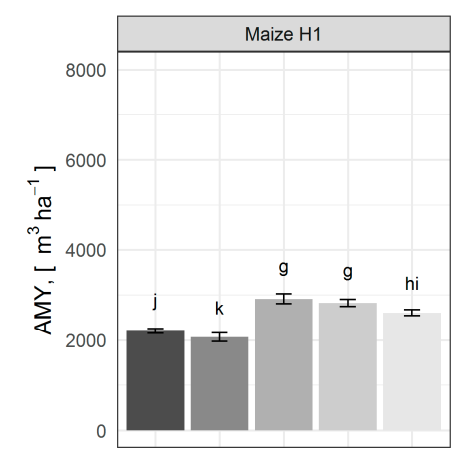

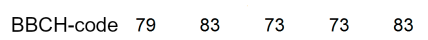

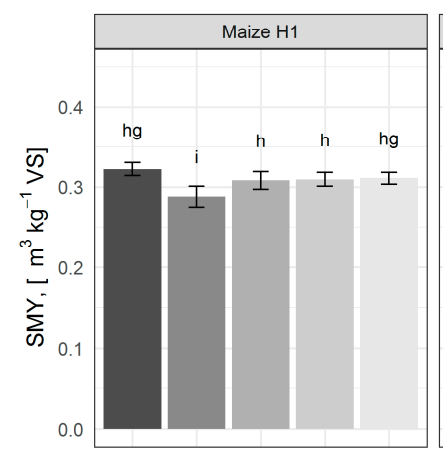

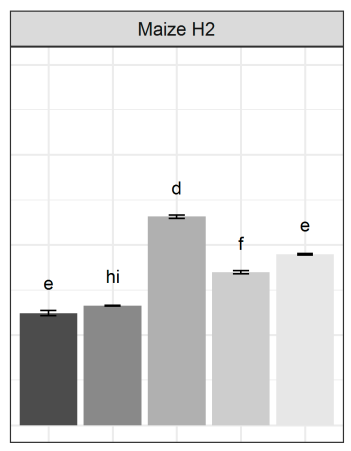

$\begin{array}{lllll}83-85 & 83-85 & 83-85 & 83-85 & 83-85\end{array}$

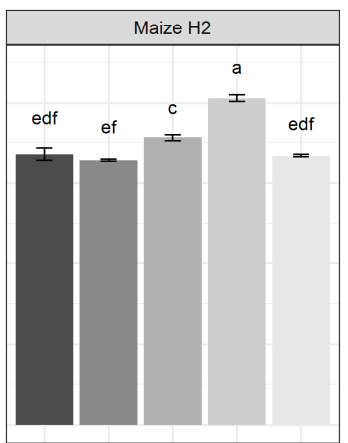

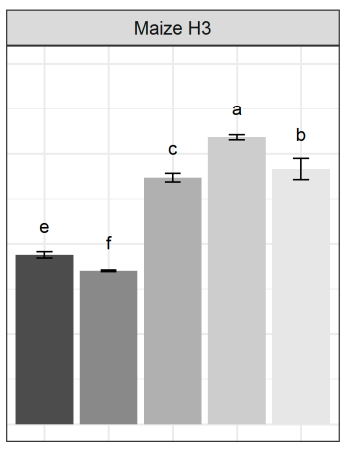

$\begin{array}{lllll}87 & 87 & 89 & 87 & 89\end{array}$

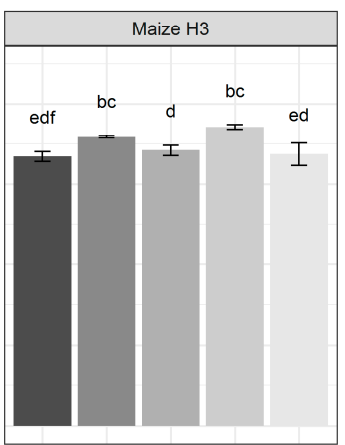

Variety

Kardynal MV Shedevr MV Slobozhans'kyi MV Svitanok MV Varta MV

Figure 2. Specific methane yield (SMY) and areal methane yield (AMY) of the maize varieties harvested at $\mathrm{H} 1, \mathrm{H} 2$ and $\mathrm{H} 3$ harvesting times, which correspond to a certain $\mathrm{BBCH}$-code related to a specific stage of crop phenological development. Histograms are charted based on the mean values; error bars indicate the variability between the three replications. Lower case letters indicate significant differences between all the maize samples according to the results of the Tukey test.

According to the research results for all the maize varieties, the samples harvested at $\mathrm{H} 3$ harvesting time (BBCH-codes $87-89)$ had the highest average values of $\mathrm{DM}_{\mathrm{FM}}(42.68 \pm 7.44 \%), \mathrm{VS}_{\mathrm{DM}}$ 
$(96.30 \pm 0.86 \%)$, DMY $\left(14.67 \pm 3.56 \mathrm{t}_{\mathrm{DM}} \mathrm{ha}^{-1}\right)$, crop $\mathrm{N}$ uptake $\left(135.98 \pm 47.34 \mathrm{~kg}_{\mathrm{N}} \mathrm{ha}^{-1}\right)$ and AMY $\left(4929.99 \pm 1285.53 \mathrm{~m}^{3} \mathrm{ha}^{-1}\right)$. However, the highest average values of SMY $\left(0.35 \pm 0.03 \mathrm{~m}^{3} \mathrm{~kg}^{-1} \mathrm{VS}\right)$ were measured for the maize samples harvested at $\mathrm{H} 2$ harvesting time (BBCH-codes 83-85).

As it is shown in Figure 2, the highest SMY of $0.41 \pm 0.00 \mathrm{~m}^{3} \mathrm{~kg}^{-1} \mathrm{VS}$ was measured for the variety "Svitanok MV" from the harvesting time $\mathrm{H} 2$ (BBCH-codes 83-85), while the highest AMY value $\left(6365.67 \pm 55.49 \mathrm{~m}^{3} \mathrm{ha}^{-1}\right)$ was determined for the same variety, which was harvested at $\mathrm{H} 3$ (BBCH-code 87).

For Western European countries (Austria, Belgium, Germany) specific methane yields between 0.295 and $0.430 \mathrm{~m}^{3} \mathrm{~kg}^{-1} \mathrm{VS}$ are reported [10,12,14,22,42-44], for Southern European countries (Italy, Spain) between 0.203 and $0.419 \mathrm{~m}^{3} \mathrm{~kg}^{-1} \mathrm{VS}[25,45]$ and for Northern European countries (Sweden) between 0.280 and $0.370 \mathrm{~m}^{3} \mathrm{~kg}^{-1} \mathrm{VS}$ [20]. The investigations from the different countries show that areal methane yields of between 2900 and $12,390 \mathrm{~m}^{3} \mathrm{ha}^{-1}$ can be achieved with maize silage [12,22,43,44], with large fluctuations between the individual years. The results of these investigations on the specific methane yields are in the middle range of those values for the Western European countries. The data on areal methane yields should be verified in multi-year studies.

\subsection{Sweet Sorghum}

Four varieties of sweet sorghum (species Sorghum saccharatum (L.) Moench) were analysed: "Sylosne 42", "Favoryt", "Zubr", and "Mamont". The selected varieties have the following characteristics and recommended growing zones in Ukraine: "Sylosne 42" and "Favoryt" grow best in the Polesia zone with mid-ripening group of ripeness; "Zubr" grows best in the steppe and forest-steppe; "Mamont" grows best in the steppe zone with mid-ripening group of ripeness.

The values of $\mathrm{DM}_{\mathrm{FM}}, \mathrm{VS}_{\mathrm{DM}}$, DMY and crop N uptake are provided in Table 4; the SMY, AMY and $\mathrm{BBCH}$-codes of the sweet sorghum samples are given in Figure 3.

Table 4. Sweet sorghum: DM and VS- content at harvest time, dry matter yield per hectare and $\mathrm{N}$-uptake. Units are given in square brackets. Values are given as mean; standard deviation is given in round brackets.

\begin{tabular}{|c|c|c|c|c|c|}
\hline Cultivar & $\begin{array}{c}\text { Harvesting } \\
\text { Time }\end{array}$ & $\mathrm{DM}_{\mathrm{FM}}{ }^{*},[\%]$ & $\mathrm{VS}_{\mathrm{DM}}{ }^{* *},[\%]$ & $\begin{array}{l}\text { DMY } \\
{\left[\mathbf{t}_{\mathrm{DM}} \mathrm{ha}^{-1}\right]}\end{array}$ & $\begin{array}{c}\text { Crop N Uptake, } \\
{\left[\mathrm{kg}_{\mathrm{N}} \mathrm{ha}^{-1}\right]}\end{array}$ \\
\hline Favoryt & $\mathrm{H} 1$ & $19.7(0.89)$ & $92.6(4.17)$ & $14.2(0.64)$ & $136.8(6.16)$ \\
\hline Mamont & H1 & $24.0(1.08)$ & $92.8(4.17)$ & $17.8(0.80)$ & $284.6(12.8)$ \\
\hline Sylosne 42 & $\mathrm{H} 1$ & $22.3(1.00)$ & $94.1(4.24)$ & $11.0(0.49)$ & $76.8(3.46)$ \\
\hline Zubr & $\mathrm{H} 1$ & $23.8(1.07)$ & $92.8(4.18)$ & $12.7(0.57)$ & $178.1(8.01)$ \\
\hline Favoryt & $\mathrm{H} 2$ & $20.9(0.42)$ & $95.3(1.91)$ & $15.1(0.30)$ & $145.1(2.90)$ \\
\hline Mamont & $\mathrm{H} 2$ & $23.6(0.47)$ & $94.5(1.89)$ & $17.5(0.35)$ & $279.8(5.60)$ \\
\hline Sylosne 42 & $\mathrm{H} 2$ & $22.6(0.45)$ & $94.1(1.88)$ & $11.1(0.22)$ & $77.9(1.56)$ \\
\hline Zubr & $\mathrm{H} 2$ & $24.1(0.48)$ & $92.3(1.85)$ & $12.9(0.26)$ & $180.3(3.61)$ \\
\hline Favoryt & H3 & $24.0(0.67)$ & $95.9(2.68)$ & $17.4(0.49)$ & $166.7(4.67)$ \\
\hline Mamont & $\mathrm{H} 3$ & $23.4(0.66)$ & $95.1(2.66)$ & $17.3(0.49)$ & 277.5 (7.77) \\
\hline Sylosne 42 & H3 & $23.8(0.67)$ & $94.9(2.66)$ & $11.67(0.33)$ & $81.8(2.29)$ \\
\hline Zubr & $\mathrm{H} 3$ & $24.8(0.69)$ & $95.8(2.68)$ & $13.3(0.37)$ & $185.6(5.20)$ \\
\hline
\end{tabular}

* The dry matter content related to fresh matter, ${ }^{* *}$ Volatile solids content related to dry matter, ${ }^{* * *}$ Dry matter yield. 

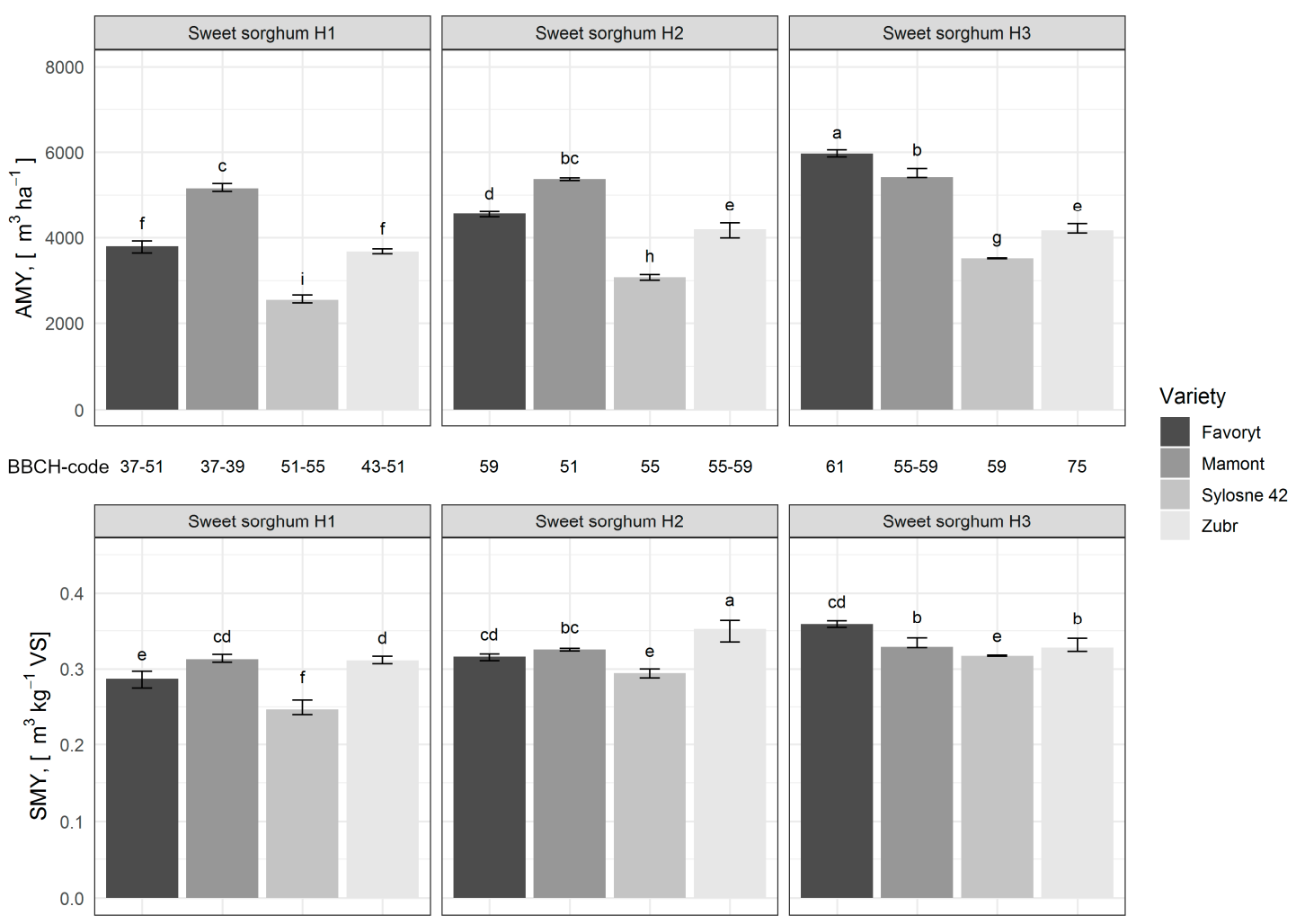

Figure 3. Specific methane yield (SMY) and areal methane yield (AMY) of the sweet sorghum varieties harvested at $\mathrm{H} 1, \mathrm{H} 2$ and $\mathrm{H} 3$ harvesting times, which correspond to a certain $\mathrm{BBCH}$-code related to a specific stage of crop phenological development. Histograms are charted based on the mean values; error bars indicate the variability between the three replications. Lower case letters indicate significant differences between all the maize samples according to the results of the Tukey test.

The vegetation stages of the samples for the three analysed harvesting times varied between the stage of shooting/the appearance of the last leaf (BBCH-code 37) and the mid-stage of milk ripeness (BBCH-code 75). The $\mathrm{H} 3$ harvesting time was related to the period between the mid-stage of inflorescence (earing) and the mid-stage of milk ripeness (BBCH-codes 55-75). The sweet sorghum samples harvested at $\mathrm{H} 3$ had the highest average values of $\mathrm{DM}_{\mathrm{FM}}(23.99 \pm 0.59 \%), \mathrm{VS}_{\mathrm{DM}}(95.43 \pm 0.48 \%)$, DMY $\left(14.91 \pm 2.89 \mathrm{t}_{\mathrm{DM}} \mathrm{ha}^{-1}\right)$, crop N uptake $\left(177.88 \pm 80.26 \mathrm{~kg}_{\mathrm{N}} \mathrm{ha}^{-1}\right)$, SMY $\left(0.33 \pm 0.02 \mathrm{~m}^{3} \mathrm{~kg}^{-1} \mathrm{VS}\right)$ and AMY $\left(4767.17 \pm 1125.41 \mathrm{~m}^{3} \mathrm{ha}^{-1}\right)$.

As shown in Figure 3, the highest SMY of $0.35 \pm 0.02 \mathrm{~m}^{3} \mathrm{~kg}^{-1} \mathrm{VS}$ was measured for the variety "Zubr" from the harvesting time $\mathrm{H} 2$ (BBCH-codes 55-59), while the highest AMY value of $5968.90 \pm 82.70 \mathrm{~m}^{3} \mathrm{ha}^{-1}$ was determined for the variety "Favoryt" harvested at $\mathrm{H} 3$ (BBCH-code 61).

For sorghum from Western European countries (Germany), specific methane yields between 0.263 and $0.328 \mathrm{~m}^{3} \mathrm{~kg}^{-1} \mathrm{VS}$ are reported [10,43]; for Southern European countries (Italy, Spain), the SMY varied between 0.240 and $0.386 \mathrm{~m}^{3} \mathrm{~kg}^{-1} \mathrm{VS}$ [25,45]. For German sorghum, areal methane yields of between 2900 and $3722 \mathrm{~m}^{3} \mathrm{ha}^{-1}$ can be achieved [43]. The results of these investigations on the specific methane yields are in the middle range of those values for the Southern European countries. The maximal results of the areal methane yields determined for Ukrainian sorghum were higher than those values for German sorghum. However, the data on areal methane yields should be verified in multi-year studies.

\subsection{Miscanthus}

For biogas production from perennial grasses, harvesting time after the ear-emergence stage is recommended [12]. According to Kiesel and Lewandowski (2017) [15], the SMY of miscanthus 
decreases with later harvesting times, and the AMY obtained from miscanthus is positively correlated with its DMY and SMY.

Two varieties of miscanthus bred and patented by the Institute of Bioenergy Crops and Sugar Beet of Ukraine for energy purposes were analysed in this study:

- $\quad$ Species Giant Chinese Silver Grass: Miscanthus x giganteus J.M Greef E Deuter ex Hodkinson Renvoiz, the variety name "Osinnii zoretsvit". We refer to the analysed variety simply as "Giganteus".

- Species Chinese Silver Grass: Miscanthus sinensis Anderss., the variety name "Misiachnyi promin". We refer to this variety simply as "Sinensis".

Both analysed miscanthus varieties are recommended for growing in the Polesia and the forest-steppe zones in Ukraine.

As it is stated in literature $[11,16,46]$, the age of plantation and environmental factors, such as site, climate and weather conditions, have a direct impact on miscanthus yields, furthermore, mature or stabilized crop yields start from second to fourth year of vegetation and last for at least 15 years. The year of vegetation corresponds to the age of miscanthus rhizomes in soil. For this reason, both analysed miscanthus varieties were harvested from the 3rd vegetation year. For examining whether there is an effect of the age of miscanthus on its SMY and AMY, the miscanthus "Giganteus" (variety "Osinnii zoretsvit") from the 8th vegetation year was additionally analysed.

The values of $\mathrm{DM}_{\mathrm{FM}}, \mathrm{VS}_{\mathrm{DM}}$, DMY and crop $\mathrm{N}$ uptake are provided in Table 5; the SMY, AMY and $\mathrm{BBCH}$-codes of the miscanthus samples are given in Figure 4.

Table 5. Miscanthus: DM and VS- content at harvest time, dry matter yield per hectare and N-uptake. Units are given in square brackets. Values are given as mean; standard deviation is given in round brackets.

\begin{tabular}{|c|c|c|c|c|c|}
\hline Cultivar, Vegetation Year & $\begin{array}{c}\text { Harvesting } \\
\text { Time }\end{array}$ & $\mathrm{DM}_{\mathrm{FM}}{ }^{*},[\%]$ & $\mathrm{VS}_{\mathrm{DM}}{ }^{* *},[\%]$ & $\begin{array}{c}\text { DMY } \\
{\left[t_{\text {DM }} h^{* * 1}\right.} \\
\end{array}$ & $\begin{array}{c}\text { Crop N Uptake, } \\
{\left[\mathrm{kg}_{\mathrm{N}} \mathrm{ha}^{-1}\right]}\end{array}$ \\
\hline Giganteus, 3rd year & H1 & $44.4(2.00)$ & $93.8(4.22)$ & $20.5(0.92)$ & $115.0(5.18)$ \\
\hline Giganteus, 8th year & $\mathrm{H} 1$ & $45.6(2.05)$ & $92.9(4.18)$ & $27.5(1.24)$ & $110.1(4.96)$ \\
\hline Sinensis, 3rd year & $\mathrm{H} 1$ & $36.6(1.65)$ & $91.0(4.10)$ & $11.0(0.50)$ & $55.2(2.48)$ \\
\hline Giganteus, 3rd year & $\mathrm{H} 2$ & $45.6(0.91)$ & $97.5(1.95)$ & $21.1(0.42)$ & $118.0(2.36)$ \\
\hline Giganteus, 8th year & $\mathrm{H} 2$ & $46.9(0.94)$ & $96.8(1.94)$ & $28.3(0.57)$ & $113.3(2.27)$ \\
\hline Sinensis, 3rd year & $\mathrm{H} 2$ & $38.6(0.77)$ & $94.4(1.89)$ & $11.6(0.23)$ & $58.2(1.16)$ \\
\hline Giganteus, 3rd year & $\mathrm{H} 3$ & $48.9(1.37)$ & $95.5(2.67)$ & $22.6(0.63)$ & $126.7(3.55)$ \\
\hline Giganteus, 8th year & H3 & $50.4(1.41)$ & $96.8(2.71)$ & $30.4(0.85)$ & $121.7(3.41)$ \\
\hline Sinensis, 3rd year & $\mathrm{H} 3$ & $44.1(1.23)$ & $93.1(2.61)$ & $13.3(0.37)$ & $66.5(1.86)$ \\
\hline
\end{tabular}

${ }^{*}$ The dry matter content related to fresh matter, ${ }^{* *}$ Volatile solids content related to dry matter, ${ }^{* * *}$ Dry matter yield.

The samples were harvested in the period between the stem elongation, booting and before the inflorescence emergence stage (BBCH-codes 36-47). All miscanthus samples had the highest average $\mathrm{DM}_{\mathrm{FM}}(47.80 \pm 3.29 \%)$ when harvested at $\mathrm{H} 3$ (BBCH-codes $\left.41-47\right)$. The highest average $\mathrm{VS}_{\mathrm{DM}}$ content $(95.13 \pm 1.90 \%)$ was measured for the samples harvested at $\mathrm{H} 2$ (BBCH-codes 39-43). All tested varieties showed the highest average DMY $\left(22.12 \pm 8.57 \mathrm{t}_{\mathrm{DM}} \mathrm{ha}^{-1}\right)$ during the third harvesting period. However, the DMY values for "Giganteus" varied between the samples from different vegetation years. The maximum DMY $\left(30.43 \pm 0.85 \mathrm{t}_{\mathrm{DM}} \mathrm{ha}^{-1}\right)$ was determined for "Giganteus" from the 8th vegetation year harvested at $\mathrm{H} 3$ (BBCH-code 41). The highest average crop N uptake $\left(104.97 \pm 33.38 \mathrm{~kg}_{\mathrm{N}} \mathrm{ha}^{-1}\right)$ of miscanthus is related to the $\mathrm{H} 3$ harvesting time. Nonetheless, $\mathrm{N}$ uptake varied between the varieties: at $\mathrm{H} 3$ the uptake for "Sinensis" was $66.50 \pm 1.86 \mathrm{~kg}_{\mathrm{N}} \mathrm{ha}^{-1}$ (BBCH-code 47), while for two "Giganteus" samples from $\mathrm{H} 3$ the determined average crop $\mathrm{N}$ uptake was $124.19 \pm 0.10 \mathrm{~kg}_{\mathrm{N}} \mathrm{ha}^{-1}$ (BBCH-code 41). In spite of that, the highest average SMY of $0.26 \pm 0.04 \mathrm{~m}^{3} \mathrm{~kg}^{-1} \mathrm{VS}$ and the highest average AMY of $4805.44 \pm 2357.94 \mathrm{~m}^{3} \mathrm{ha}^{-1}$ corresponded to the crop samples from H1 (BBCH-codes 36-39). There was also a big difference in SMY between the samples. The highest SMY $\left(0.29 \pm 0.02 \mathrm{~m}^{3} \mathrm{~kg}^{-1} \mathrm{VS}\right)$ and the highest AMY $\left(7404.55 \pm 199.00 \mathrm{~m}^{3} \mathrm{ha}^{-1}\right)$ were measured for "Giganteus" from the 8th vegetation year harvested at $\mathrm{H1}$ (BBCH-code 36). 

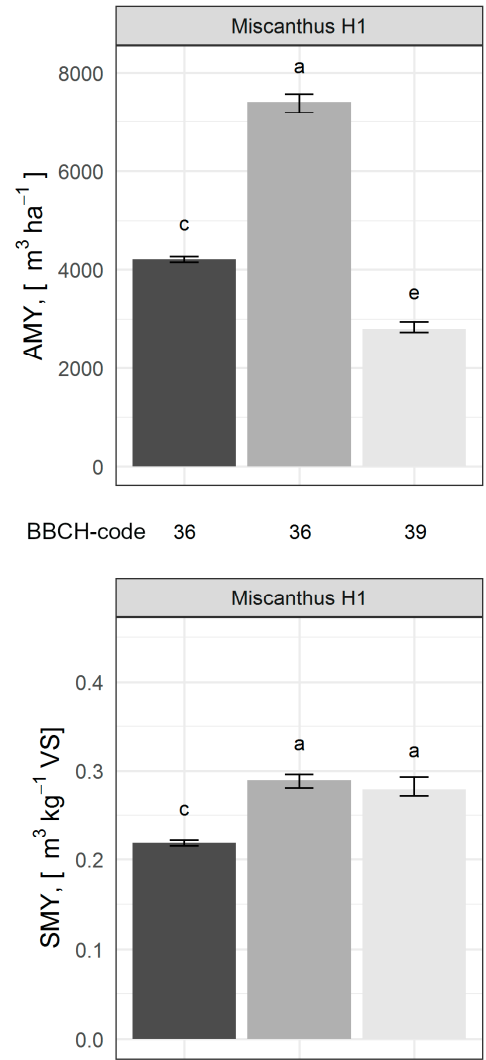

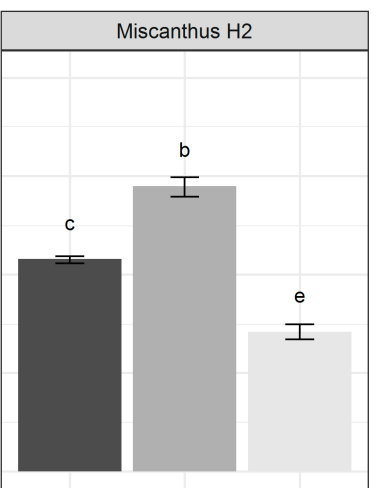

39

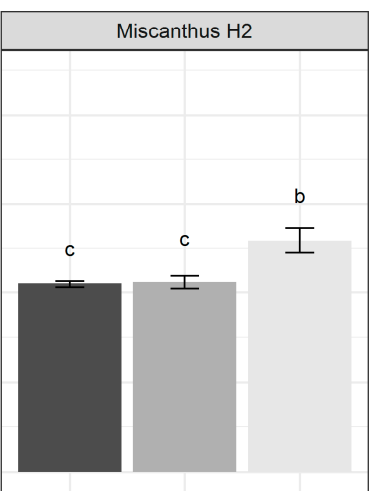

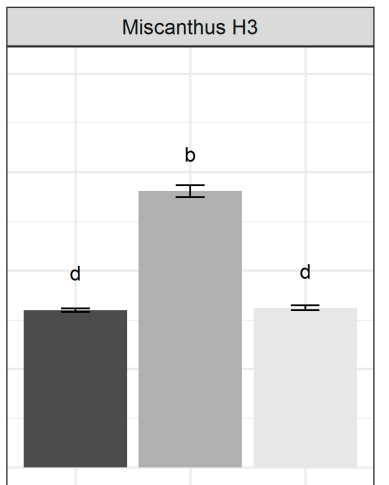

41

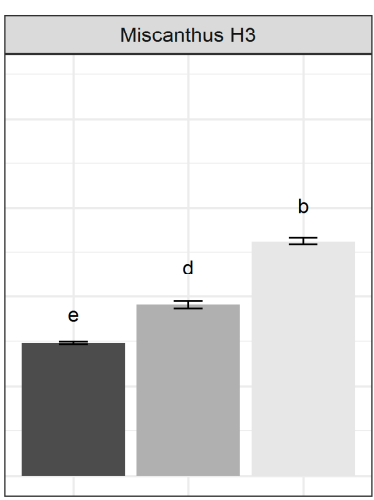

Variety

Giganteus, 3rd year Giganteus, 8th year Sinensis, 3rd year

Figure 4. Specific methane yield (SMY) and areal methane yield (AMY) of the miscanthus varieties harvested at $\mathrm{H} 1, \mathrm{H} 2$ and $\mathrm{H} 3$ harvesting times, which correspond to a certain $\mathrm{BBCH}$-code related to a specific stage of crop phenological development. The analysed varieties were: (1) Species Giant Chinese Silver Grass: Miscanthus x giganteus J.M. Greef E Deuter ex Hodkinson Renvoiz, the variety name "Osinnii zoretsvit", referred to as "Giganteus". (2) Species Chinese Silver Grass: Miscanthus sinensis Anderss., the variety name "Misiachnyi promin", referred to as "Sinensis". "Giganteus" from the 3rd and the 8th years of vegetation and "Sinensis" from the 3rd vegetation year were analysed. Histograms are charted based on the mean values; error bars indicate the variability between the three replications. Lower case letters indicate significant differences between the analysed miscanthus samples according to the results of the Tukey test.

For Germany, the specific methane yields for miscanthus between 0.179 and $0.280 \mathrm{~m}^{3} \mathrm{~kg}^{-1} \mathrm{VS}$ are reported $[10,15]$. The areal methane yields for German miscanthus varied between 2300 and $6400 \mathrm{~m}^{3} \mathrm{ha}^{-1}$ [15]. The results of these investigations are in the middle range of the values reported in the literature, except for miscanthus "Giganteus" from the 8th vegetation year with the higher SMY and AMY values.

\subsection{Data Analysis for Maize, Sweet Sorghum and Miscanthus}

A generalized linear model procedure was used for the analysis of data based on the results for maize, sweet sorghum and miscanthus. Based on the modelling results, the following conclusions can be drawn:

SMY was significantly affected by the BBCH-code $(p=0.0009)$ and by the variety $(p<0.0001)$. The highest SMY was determined for the analysed maize and sweet sorghum samples. The highest SMY values for the maize samples were related to the vegetation stage of wax to full ripeness (BBCH-codes 83-87). For sweet sorghum, the highest SMY corresponded to the period between the mid-stage of inflorescence (earing) and the flowering stage (BBCH-codes 55-61). For miscanthus, the highest SMY values were determined for the samples harvested at earlier harvesting times, which corresponded to the vegetation period between the stem elongation and booting (BBCH-codes 36-39). 
AMY was significantly affected by the BBCH-code $(p=0.0024)$ and by the variety $(p<0.0001)$. The highest AMY among the three crops was found for miscanthus "Giganteus" from the 8th vegetation year harvested at $\mathrm{H} 1\left(7404.55 \pm 199.00 \mathrm{~m}^{3} \mathrm{ha}^{-1}, \mathrm{BBCH}\right.$-code 36). For maize and sweet sorghum, the highest yields were found when collected at the third harvesting time. When harvested at $\mathrm{H} 3$, the mean AMY values for maize with the highest yields (4929.99 $\pm 1285.53 \mathrm{~m}^{3} \mathrm{ha}^{-1}, \mathrm{BBCH}$-codes 87-89) have slightly overperformed those values for sweet sorghum $\left(4767.17 \pm 1125.41 \mathrm{~m}^{3} \mathrm{ha}^{-1}, \mathrm{BBCH}\right.$-codes $\left.55-75\right)$. Thus, the AMY of miscanthus was about $50 \%$ higher than that of the traditional energy crops maize and sweet sorghum. Miscanthus has an additional advantage of being a perennial crop, which can be cultivated for more than 20 years; moreover, this crop can be grown on marginal and contaminated lands for soil phytoremediation [16,47]. Furthermore, the cultivation costs for miscanthus are lower, than those for maize and sweet sorghum. In further studies, SMY and AMY of miscanthus under other vegetation years up to the death of plantation have to be further investigated.

\subsection{Other Analysed Crops}

In addition to the "traditional" energy crops, also soybean, soriz, switchgrass and paulownia had been analysed according to their methane yield potential. These results are provided in Table 6 . Soybean (Glycine max (L.) Merrill) can be successfully grown in rotation with a large variety of other plants [11], as well as in widely diverse climates and on varied soil types [48]. Soriz (Sorghum oryzoidum) is a hybrid of sorghum and rice, which was selected for this study for being nonexacting to soil with lodging resistance, as well as with resistance to smut diseases and lice [29]. Switchgrass (Panicum virgatum $L$.) is a perennial plant, which is valued for its soil stabilizing, phytoremediation and windbreaking capacities in crop fields [16,31]. Paulownia (Paulownia Sieb. et Zucc., species P. tomentosa $x$ P. fortunei) is a very fast-growing plant, which is extremely adaptive to a wide range of soils and climatic conditions and can also be grown on marginal lands [34,49].

Table 6. Soybean, soriz, switchgrass and paulownia: DM and VS- content at harvest time, dry matter yield per hectare and N-uptake. Units are given in square brackets. Values are given as mean; standard deviation is given in round brackets.

\begin{tabular}{|c|c|c|c|c|c|c|c|}
\hline Crop & $\begin{array}{l}\text { Analysed } \\
\text { Cultivars }\end{array}$ & $\underset{[\%]}{\mathrm{DM}_{\mathrm{FM}}}$ & $\begin{array}{c}\mathrm{VS}_{\mathrm{DM}} \\
{[\%]}\end{array}$ & $\begin{array}{l}\text { DMY }{ }^{* * *}, \\
{\left[\mathrm{t}_{\mathrm{DM}} \mathrm{ha}^{-1}\right]}\end{array}$ & $\begin{array}{l}\text { Crop N Uptake, } \\
{\left[\mathrm{kg}_{\mathrm{N}} \mathrm{ha}^{-1}\right]}\end{array}$ & $\begin{array}{c}\text { SMY, } \\
{\left[\mathrm{Nm}^{3 * * * *}\right.} \\
\left.\mathrm{kg}^{-1} \mathrm{VS}\right]\end{array}$ & $\begin{array}{c}\text { AMY, } \\
{\left[\mathrm{Nm}^{3} \mathrm{ha}^{-1}\right]}\end{array}$ \\
\hline Soybean & $\begin{array}{l}\text { "Diona", } \\
\text { "Muza", } \\
\text { "Sharm", } \\
\text { "Sprytna" }\end{array}$ & $28.88(4.74)$ & $90.17(2.76)$ & $1.41(0.71)$ & 20.47 (9.72) & $0.266(0.025)$ & 341.77 (183.31) \\
\hline Soriz & $\begin{array}{l}\text { "Kvarts", } \\
\text { "Saliut", } \\
\text { "Titan" }\end{array}$ & $16.32(3.07)$ & $92.16(1.89)$ & $3.81(1.21)$ & $0.06(0.02)$ & $0.329(0.006)$ & $\begin{array}{l}1164.05 \\
(407.62)\end{array}$ \\
\hline Switchgrass & $\begin{array}{l}\text { "Morozko" } \\
\text { from the } \\
\text { 2nd and } \\
\text { the 8th } \\
\text { vegetation } \\
\text { years }\end{array}$ & $38.21(5.77)$ & $95.21(0.82)$ & $2.99(0.89)$ & $24.78(4.24)$ & $0.258(0.006)$ & $732.77(210.23)$ \\
\hline Paulownia & "Shantong" & $25.87(0.01)$ & $83.47(5.58)$ & $7.08(0.36)$ & $56.66(2.85)$ & $0.231(0.055)$ & $\begin{array}{l}1363.95 \\
(329.73)\end{array}$ \\
\hline
\end{tabular}

* The dry matter content related to fresh matter, ${ }^{* *}$ Volatile solids content related to dry matter, ${ }^{* *}$ Dry matter yield, **** $\mathrm{Nm}^{3}\left(273^{\circ} \mathrm{K}, 1.013\right.$ bar $)$.

For switchgrass, specific methane yields between 0.191 and $0.309 \mathrm{~m}^{3} \mathrm{~kg}^{-1} \mathrm{VS}$ are reported for South European countries (Spain) [25]. Similar SMY were measured for switchgrass from Canada (between 0.210 and $0.365 \mathrm{~m}^{3} \mathrm{~kg}^{-1}$ VS) with an AMY between 1500 and $3280 \mathrm{~m}^{3} \mathrm{ha}^{-1}$ [21]. The results of these investigations on the specific methane yields from Ukrainian switchgrass are in the middle range 
of those values reported in the literature. However, the maximal results of the areal methane yields determined for Canadian switchgrass were higher than those values achieved in our study.

\subsection{Influence of DMY on AMY}

For all the analysed samples, when comparing DMY and AMY, a high correlation $\left(R^{2}=0.97\right)$ significant at the 0.001 probability level was found (see Figure 5). A rather small correlation was identified for only the samples from miscanthus "Giganteus". With the exception of paulownia and miscanthus "Giganteus", almost all varieties for all analysed crops have shown higher AMY values at higher DMY, harvested at the later stage of maturity.

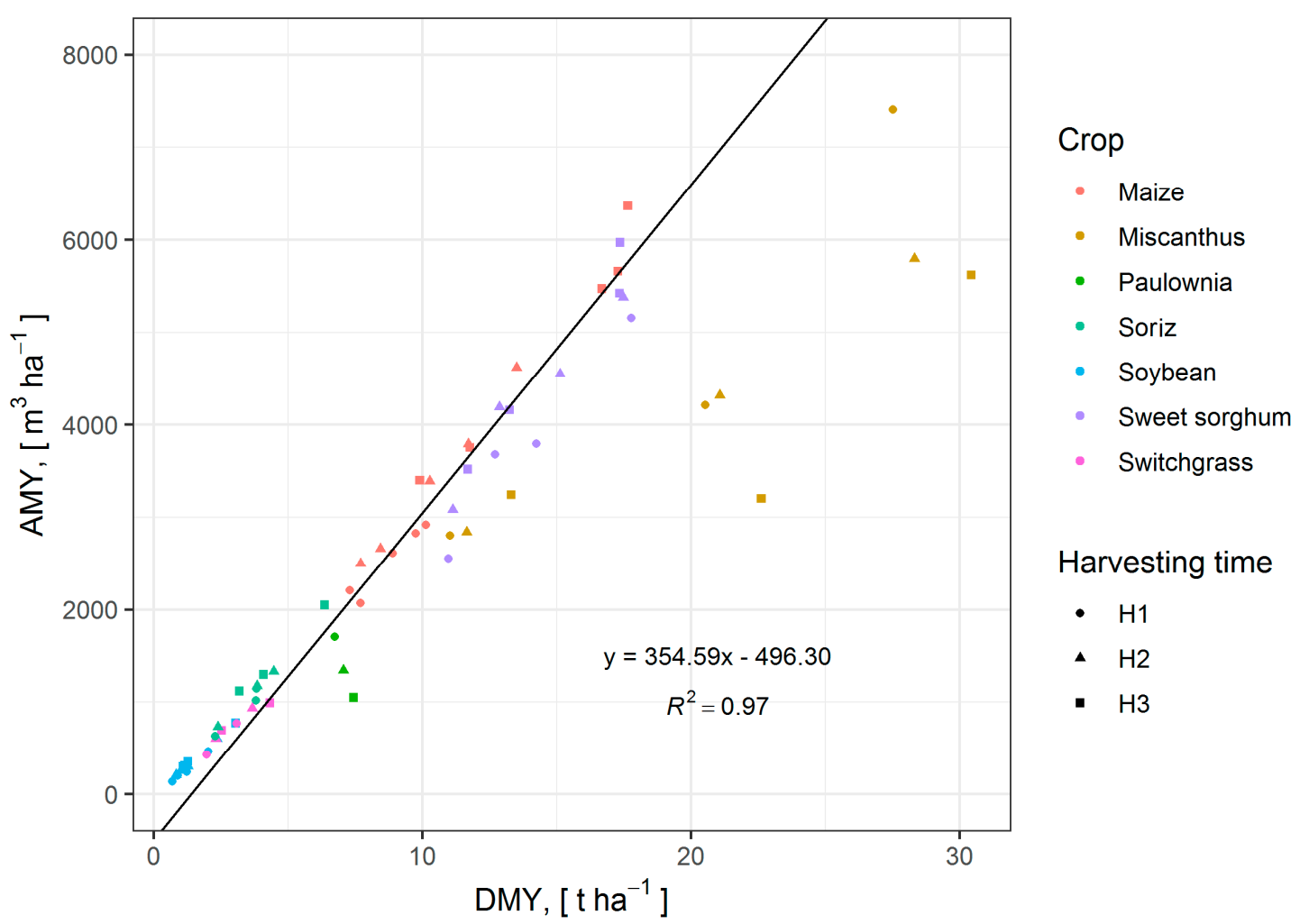

Figure 5. Correlation between dry matter yield (DMY) in $\mathrm{t} \mathrm{ha}^{-1}$ and areal methane yield (AMY) in $\mathrm{m}^{3} \mathrm{ha}^{-1}$ for the total of 22 varieties from 7 crops harvested in three harvesting times (H1, H2 and H3) in 2017 (total amount of samples $n=66$ ).

\subsection{Influence of Crop N Uptake on AMY}

Crop $\mathrm{N}$ uptake is related to crop $\mathrm{N}$ demand, the dosage of fertilizer supplied, and the $\mathrm{N}$ contents in soil $[50,51]$. The generalised mechanism of $\mathrm{N}$ uptake by plants related to $\mathrm{N}$ supply is described by Lawlor [51]. A small correlation $\left(R^{2}=0.29\right.$, significant at the 0.001 probability level) was found between the crop N uptake and the AMY values for all the analysed samples (see Figure 6). The crop $\mathrm{N}$ uptake varied depending on plant, variety and harvesting time. 


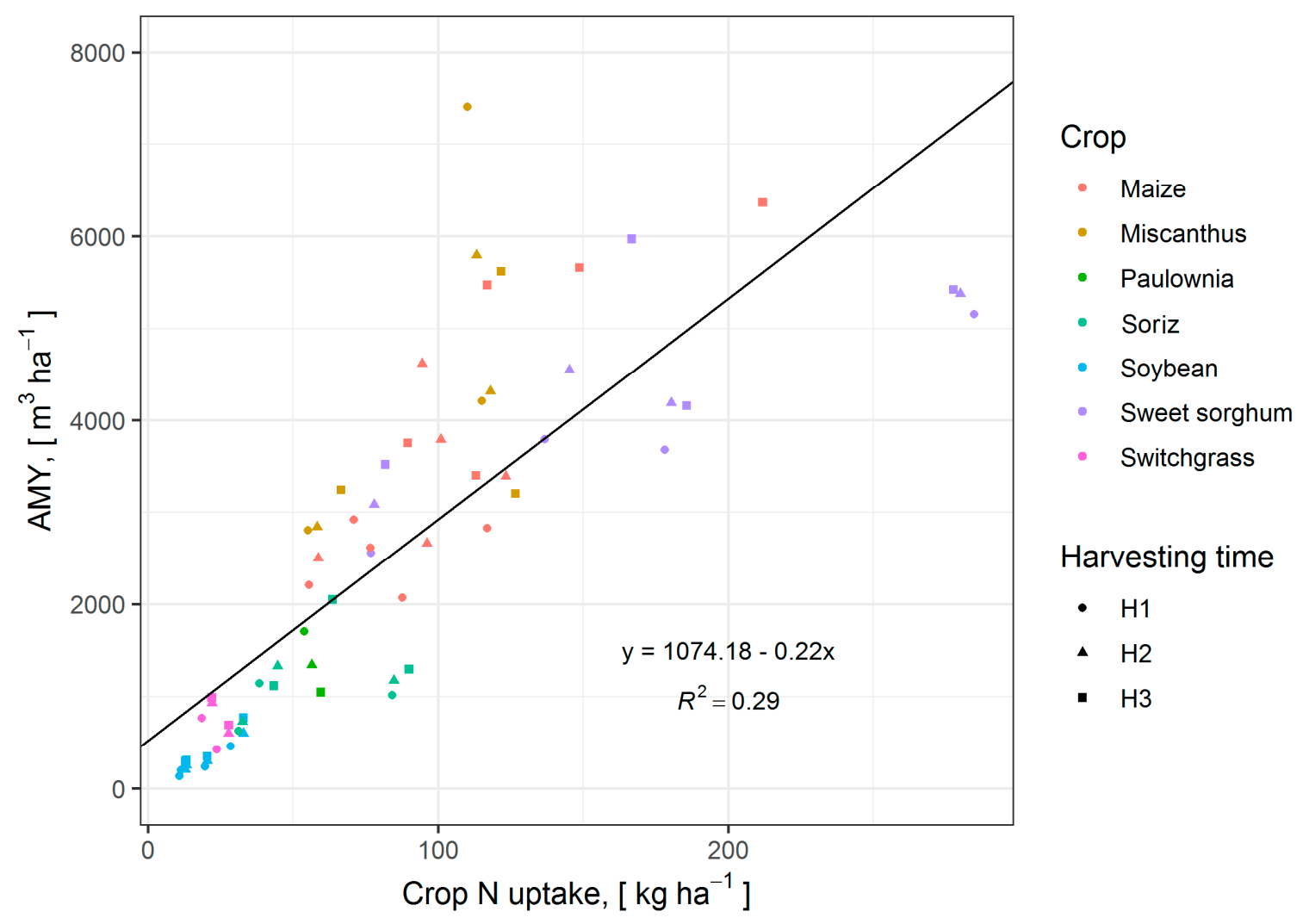

Figure 6. Correlation between crop nitrogen (N) uptake in $\mathrm{kg} \mathrm{ha}^{-1}$ and areal methane yield (AMY) in $\mathrm{m}^{3} \mathrm{ha}^{-1}$ for the total of 22 varieties from 7 crops harvested in three harvesting times (H1, H2 and H3) in 2017 (total amount of samples $n=66$ ).

Among all the analysed research crops, miscanthus has the lowest $\mathrm{N}$-demand per $1 \mathrm{~m}^{3}$ methane produced $\left(23.41 \pm 7.18 \mathrm{~g}_{\mathrm{N} \mathrm{m}} \mathrm{m}^{-3}\right)$. Maize has higher $\mathrm{N}$-demand than miscanthus, but is more efficient in $\mathrm{N}$-use compared to other analysed crops $\left(29.58 \pm 7.13 \mathrm{~g}_{\mathrm{N}} \mathrm{m}^{-3}\right)$. Switchgrass and sweet sorghum continue this list with their $\mathrm{N}$-demand of $36.84 \pm 13.87 \mathrm{~g}_{\mathrm{N} \mathrm{m}} \mathrm{m}^{-3}$ and $39.08 \pm 11.35 \mathrm{~g}_{\mathrm{N}} \mathrm{m}^{-3}$, respectively. Paulownia, soriz and soybean are the least efficient in $\mathrm{N}$ use for producing $1 \mathrm{~m}^{3}$ methane among all the analysed plants.

\section{Conclusions}

In this study, Ukrainian energy crops were harvested at different harvesting times, related to the different stages of crop phenological development and analysed according to their dry matter content, volatile solids content, dry matter yield, crop nitrogen uptake, specific methane yield, and areal methane yield. Miscanthus, sweet sorghum and maize are, in that order, particularly well suited for use as energy crops in Ukraine. Whereas the AMY of maize and sweet sorghum are mainly influenced by DMY of the crops, the SMY of miscanthus has a great influence on its methane yield per hectare. In relation to the biogas formation potential, miscanthus and silage maize showed the highest nitrogen use efficiency. This means that they have the lowest $\mathrm{N}$ requirement relative to biogas formation. For the continental climate of Ukraine, miscanthus appears to be the most interesting energy crop under the aspects of cultivation costs, methane yield per area and nitrogen use efficiency.

Author Contributions: Conceptualization: I.M., A.L., M.R.; data curation: I.M., B.H.; formal analysis: I.M., B.H.; funding acquisition: H.O., A.L., I.M.; investigation: I.M., B.H.; project administration; I.M., H.O., A.L., M.R.; resources: H.O., A.L., M.R.; supervision: A.L.; visualization: I.M.; writing—original draft: I.M.; writing一review \& editing: A.L., I.M., B.H. All authors have read and agreed to the published version of the manuscript. 
Funding: This research was supported by the German Academic Exchange Service (Deutscher Akademischer Austauschdienst, DAAD) and the State Institute of Agricultural Engineering and Bioenergy, University of Hohenheim. The APC was partly funded by the German Academic Exchange Service.

Acknowledgments: We would like to thank the Institute of Bioenergy Crops and Sugar Beet of Ukraine for the assistance with the cultivation of the crops. We want to thank Nina Morozova for her valuable help with harvesting and pretreatment of the samples. We are grateful Volodymyr Kvak, Valery Katelevsky, Mykhaylo Gumentyk, Oleksandr Ganzhenko, Pavlo Zykov, Viktor Sinchenko, Iryna Boiko, Galyna Sinchuk, Nadiia Kononyuk, Galyna Tsvigun, Liudmyla Pravdyva, Vadym Ivanina, Iryna Strigun and Oleksandra Tryboi for their advisory services and assistance with the laboratory analysis of the crop samples in Ukraine.

Conflicts of Interest: The authors declare no conflicts of interest.

\section{References}

1. State Statistics Service of Ukraine. Available online: http://www.ukrstat.gov.ua/ (accessed on 19 June 2020).

2. Scarlat, N.; Dallemand, J.-F.; Fahl, F. Biogas: Developments and perspectives in Europe. Renew. Energy 2018, 129, 457-472. [CrossRef]

3. State Agency on Energy Efficiency and Energy Saving of Ukraine. Ukraine, There Operate Biogas Plants with a Total Capacity of 70 MW (В Україні працюють біогазові установки загальною потужністю 70 МВт). Available online: https:/www.kmu.gov.ua/news/derzhenergoefektivnosti-v-ukrayini-pracyuyut-biogazoviustanovki-zagalnoyu-potuzhnistyu-70-mvt (accessed on 4 February 2020).

4. Babych, M.M. Food security indicators in Ukraine: Development trends (Індикатори продовольчої безпеки в Україні: тенденції розвитку). Ekonomika APK 2018, 5, 41-50.

5. State Service of Ukraine for Geodesy, Cartography \& Cadastre. The Land Fund of Ukraine as of January 1, 2016 and the Dynamics of its Changes Compared to the Data as of January 1, 2015. (Земельний фонд України станом на 1 січня2016 року та динаміка його змін у порівнянні з даними на 1 січня2015 року). Available online: https://land.gov.ua/info/zemelnyi-fond-ukrainy-stanom-na-1-sichnia-2016-roku-tadynamika-ioho-zmin-u-porivnianni-z-danymy-na-1-sichnia-2015-roku/ (accessed on 30 March 2020).

6. SEEMLA Project-Horizon. 2020. Available online: https://www.seemla.eu/ukraine/ (accessed on 30 March 2020).

7. Bioplat EU Project-Horizon. 2020. Available online: https://bioplat.eu/about (accessed on 30 March 2020).

8. State Agency on Energy Efficiency and Energy Saving of Ukraine. Ukraine Will Implement a Program of State Support for Bioenergy Crops. Available online: https://www.ukrinform.ua/rubric-economy/2840751-vukraini-zaprovadat-programu-derzpidtrimki-bioenergeticnih-kultur.html (accessed on 19 June 2020).

9. Lehtomäki, A. Biogas Production from Energy Crops and Crop Residues; University of Jyväskylä: Jyväskylä, Finland, 2006; ISBN 951-39-2559-5.

10. Herrmann, C.; Idler, C.; Heiermann, M. Biogas crops grown in energy crop rotations: Linking chemical composition and methane production characteristics. Bioresour. Technol. 2016, 206, 23-35. [CrossRef] [PubMed]

11. El Bassam, N. Handbook of Bioenergy Crops; Routledge: Abingdon, UK, 2010; ISBN 978-1-84407-854-7.

12. Amon, T.; Amon, B.; Kryvoruchko, V.; Machmüller, A.; Hopfner-Sixt, K.; Bodiroza, V.; Hrbek, R.; Friedel, J.; Pötsch, E.; Wagentristl, H.; et al. Methane production through anaerobic digestion of various energy crops grown in sustainable crop rotations. Bioresour. Technol. 2007, 98, 3204-3212. [CrossRef] [PubMed]

13. Hübner, M.; Oechsner, H.; Koch, S.; Seggl, A.; Hrenn, H.; Schmiedchen, B.; Wilde, P.; Miedaner, T. Impact of genotype, harvest time and chemical composition on the methane yield of winter rye for biogas production. Biomass Bioenergy 2011, 35, 4316-4323. [CrossRef]

14. Mukengele, M.M. Biochemical Composition of Biomass and its Impact on the Prediction of the Specific Methane Yield Potential; University of Hohenheim: Stuttgart, Germany, 2017.

15. Kiesel, A.; Lewandowski, I. Miscanthus as biogas substrate-cutting tolerance and potential for anaerobic digestion. GCB Bioenergy 2017, 9, 153-167. [CrossRef]

16. Zegada-Lizarazu, W.; Elbersen, H.W.; Cosentino, S.L.; Zatta, A.; Alexopoulou, E.; Monti, A. Agronomic aspects of future energy crops in Europe. Spec. Issue Biofuels Eur. 2010, 4, 674-691. [CrossRef]

17. Kotrla, M.; Prčík, M. Evaluating the Effects of Climatic Parameters on Growth and Biomass Production of Miscanthus in Climate Conditions of Southern Slovakia. Pol. J. Environ. Stud. 2019, 29, 669-675. [CrossRef] 
18. Hui, D.; Yu, C.-L.; Deng, Q.; Dzantor, E.K.; Zhou, S.; Dennis, S.; Sauve, R.; Johnson, T.L.; Fay, P.A.; Shen, W.; et al. Effects of precipitation changes on switchgrass photosynthesis, growth, and biomass: A mesocosm experiment. PLOS ONE 2018. [CrossRef]

19. Mast, B.; Lemmer, A.; Oechsner, H.; Reinhardt-Hanisch, A.; Claupein, W.; Graeff-Hönninger, S. Methane yield potential of novel perennial biogas crops influenced by harvest date. Ind. Crop. Prod. 2014, 58, $194-203$. [CrossRef]

20. Gissén, C.; Prade, T.; Kreuger, E.; Nges, I.A.; Rosenqvist, H.; Svensson, S.-E.; Lantz, M.; Mattsson, J.E.; Börjesson, P.; Björnsson, L. Comparing energy crops for biogas production-Yields, energy input and costs in cultivation using digestate and mineral fertilisation. Biomass Bioenergy 2014, 64, 199-210. [CrossRef]

21. Massé, D.; Gilbert, Y.; Savoie, P.; Bélanger, G.; Parent, G.; Babineau, D. Methane yield from switchgrass harvested at different stages of development in Eastern Canada. Bioresour. Technol. 2010, 101, 9536-9541. [CrossRef] [PubMed]

22. Schumacher, B. Studies on the Processing and Conversion of Energy Crops into Biogas and Bioethanol (Untersuchungen zur Aufbereitung und Umwandlung von Energiepflanzen in Biogas und Bioethanol); University of Hohenheim: Stuttgart, Germany, 2008.

23. Sawatdeenarunat, C.; Surendra, K.C.; Takara, D.; Oechsner, H.; Khanal, S.K. Anaerobic digestion of lignocellulosic biomass: Challenges and opportunities. Bioresour. Technol. 2015, 178, 178-186. [CrossRef] [PubMed]

24. Korres, N. Bioenergy Production by Anaerobic Digestion; Routledge: Abingdon, UK, 2013; ISBN 9780203137697.

25. Raposo, F.; De La Rubia, M.Á.; Fernández-Cegrí, V.; Borja, R. Anaerobic digestion of solid organic substrates in batch mode: An overview relating to methane yields and experimental procedures. Renew. Sust. Energy Rev. 2012, 16, 861-877. [CrossRef]

26. El-Mashad, H.M. Biomethane and ethanol production potential of Spirulina platensis algae and enzymatically saccharified switchgrass. Biochem. Eng. J. 2015, 93, 119-127. [CrossRef]

27. Agbor, V.B.; Cicek, N.; Sparling, R.; Berlin, A.; Levin, D.B. Biomass pretreatment: Fundamentals toward application. Biotechnol. Adv. 2011, 29, 675-685. [CrossRef]

28. Behera, S.; Arora, R.; Nandhagopal, N.; Kumar, S. Importance of chemical pretreatment for bioconversion of lignocellulosic biomass. Renew. Sust. Energy Rev. 2014, 36, 91-106. [CrossRef]

29. Galaev, O.V.; Shevchuk, G.Y.; Dudchenko, V.V.; Sivolap, Y.M. Molecular genetic analysis of the soriz genome (Sorghum oryzoidum). Cytol. Genet. 2011, 45, 208-213. [CrossRef]

30. Ministry of Agrarian Policy and Food. State Register of Plant Varieties Suitable for Dissemination in Ukraine in 2019 (РеєстрСортів Рослин, Придатних дляПоширення в Україні на 2019 рік); Ministry of Agrarian Policy and Food: Kyiv, Ukraine, 2019.

31. Brown, R.C.; Brown, T.R. Biorenewable Resources. Engineering New Products from Agriculture, 2nd ed.; Wiley-Blackwell: Chichester, UK, 2014; ISBN 978-1-1185-2495-4.

32. Hu, S.-Y. The Economic Botany of the Paulownias. Econ. Bot. 1961, 15, 11-27.

33. Smart, A.J.; Moser, L.E. Morphological Development of Switchgrass as Affected by Planting Date. Agron. J. 1997, 89, 958-962. [CrossRef]

34. Icka, P.; Damo, R.; Icka, E. Paulownia Tomentosa, a Fast Growing Timber. Ann. Valahia Univ. Targoviste Agricult. 2016, 10, 14-19. [CrossRef]

35. Tejera, M.D.; Heaton, E.A. Description and Codification of Miscanthus $\times$ giganteus Growth Stages for Phenological Assessment. Front. Plant Sci. 2017, 8, 1-12. [CrossRef] [PubMed]

36. Meier, U. Development Stages of Mono- and Dicotyledonous Plants (Entwicklungsstadien mono- und dikotyler Pflanzen), 2nd ed.; BBCH Monografie: Berlin, Germany, 2001.

37. American Public Health Association; American Water Works Association; Water Environment Federation. Standard Methods for the Examination of Water and Wastewater; American Public Health Association: Washington, DC, USA, 1998; ISBN 0-87553-235-7.

38. Kalra, Y.P. Handbook of Reference Methods for Plant Analysis; CRC Press: Boca Raton, FL, USA, 1998; ISBN 978-1-57444-124-6.

39. Mittweg, G.; Oechsner, H.; Hahn, V.; Lemmer, A.; Reinhardt-Hanisch, A. Repeatability of a laboratory batch method to determine the specific biogas and methane yields. Eng. Life Sci. 2012, 12, 270-278. [CrossRef]

40. VDI 4630: VDI-Society Energy and Environment. VDI 4630 Fermentation of Organic Materials. Characterization of the Substrate, Sampling, Collection of Material Data, Fermentation Tests; VDI-Verlag: Düsseldorf, Germany, 2006. 
41. Hülsemann, B.; Zhou, L.; Merkle, W.; Hassa, J.; Müller, J.; Oechsner, H. Biomethane Potential Test: Influence of Inoculum and the Digestion System. Appl. Sci. 2020, 10, 2589. [CrossRef]

42. Dandikas, V.; Heuwinkel, H.; Lichti, F.; Drewes, J.E.; Koch, K. Correlation between biogas yield and chemical composition of energy crops. Bioresour. Technol. 2014, 174, 316-320. [CrossRef] [PubMed]

43. Herrmann, C.; Prochnow, A.; Heiermann, M.; Idler, C. Particle Size Reduction During Harvesting of Crop Feedstock for Biogas Production II: Effects on Energy Balance, Greenhouse Gas Emissions and Profitability. Bioenerg. Res. 2012, 5, 937-948. [CrossRef]

44. Mayer, F.; Gerin, P.A.; Noo, A.; Foucart, G.; Flammang, J.; Lemaigre, S.; Sinnaeve, G.; Dardenne, P.; Delfosse, P. Assessment of factors influencing the biomethane yield of maize silages. Bioresour. Technol. 2014, 153, 260-268. [CrossRef]

45. Battista; Frison; Bolzonella. Energy and Nutrients' Recovery in Anaerobic Digestion of Agricultural Biomass: An Italian Perspective for Future Applications. Energies 2019, 12, 3287. [CrossRef]

46. Caslin, B.; Finnan, J.; Easson, L. Miscanthus. Best Practice Guidelines; Johnston, C., Ed.; Ecclesville Printing Services Ltd.: Belfast, UK, 2015; ISBN 1-84170-611-5.

47. Barbosa, B.; Boléo, S.; Sidella, S.; Costa, J.; Duarte, M.P.; Mendes, B.; Cosentino, S.L.; Fernando, A.L. Phytoremediation Potential of Heavy Metal Contaminated Soils by the Perennial Energy Crops Miscanthus SPP. and Arundo Donax L. under Low Irrigation; ETA-Florence Renewable Energies: Florence, Italy, 2018.

48. Bennett, J.M.; Hicks, D.R.; Naeve, S.L.; Minnesota Soybean Growers Association. The Minnesota Soybean Field Book; University of Minnesota Extension Service: Minneapolis, MN, USA, 1999.

49. Yadav, N.K.; Vaidya, B.N.; Henderson, K.; Lee, J.F.; Stewart, W.M.; Dhekney, S.A.; Joshee, N. A Review of Paulownia Biotechnology: A Short Rotation, Fast Growing Multipurpose Bioenergy Tree. AJPS 2013, 4, 2070-2082. [CrossRef]

50. Chen, P.; Du, Q.; Liu, X.; Zhou, L.; Hussain, S.; Lei, L.; Song, C.; Wang, X.; Liu, W.; Yang, F.; et al. Effects of reduced nitrogen inputs on crop yield and nitrogen use efficiency in a long-term maize-soybean relay strip intercropping system. PLoS ONE 2017, 12, e0184503. [CrossRef]

51. Lawlor, D. Carbon and nitrogen assimilation in relation to yield: Mechanisms are the key to understanding production systems. J. Exp. Bot. 2002, 53, 773-787. [CrossRef] [PubMed]

(C) 2020 by the authors. Licensee MDPI, Basel, Switzerland. This article is an open access article distributed under the terms and conditions of the Creative Commons Attribution (CC BY) license (http://creativecommons.org/licenses/by/4.0/). 